\title{
Dinamika Struktur Leverage dan Rating Obligasi Perusahaan yang Terdaftar Di Bursa Efek Indonesia
}

\author{
Deni Ramdani ${ }^{1}$ dan Chaidir Iswanaji ${ }^{2}$ \\ 1Jurusan Manajemen Universitas Tidar Magelang \\ 2Jurusan Akuntansi Universitas Tidar Magelang \\ Jl. Kapten S. Parman No. 39, Magelang, 56116, Indonesia
}

\section{Info Article}

History Article:

Approved: 10 December 2018

Published: 25 December 2018

Keywords:

Rating obligation; Leverage;

Debt Ratio

ISSN (print) : 2598-7763

ISSN (online): 2598-7771

\begin{abstract}
Abtract
This study aims to examine and investigate related leverage, bond rating of companies listed on the Indonesian stock exchange. The increase in the amount of leverage will not have an impact on the downgrade of the company as long as the increase in leverage has an impact on increasing the profitability and larger size of the company. Companies increase leverage through debt issuance substantively responding to operating needs rather than the desire to make large equity payments. Samples taken in the study of 20 manufacturing companies with purposive sampling method for the period 2012-2016. Bond rating release by PT. Pefindo and ICMD 2012-2016. Leverage ratios consisting of Debt to Equity Ratio (DER), Debt to Total Asset Ratio (DAR), Degree of Financial Leverage (DFL), and Debt Coverage Ratio (DCR) cannot predict the company's bond rating. The research findings show that leverage has no effect on bond ratings.
\end{abstract}

Citation: Ramdani, Deni dan Iswanaji, Chaidir (2018). Dinamika Struktur Leverage dan Rating Obligasi Perusahaan yang Terdaftar Di Bursa Efek Indonesia. Accounting and Financial Review, 1 (2)

\begin{abstract}
Abstraks
Penelitian ini bertujuan untuk menguji dan menyelidiki leverage terkait, peringkat obligasi perusahaan yang terdaftar di bursa efek Indonesia. Peningkatan jumlah leverage tidak akan berdampak pada penurunan peringkat perusahaan selama peningkatan leverage berdampak pada peningkatan profitabilitas dan ukuran perusahaan yang lebih besar. Perusahaan meningkatkan leverage melalui penerbitan utang secara substansial menanggapi kebutuhan operasi daripada keinginan untuk melakukan pembayaran ekuitas besar. Sampel diambil dalam studi 20 perusahaan manufaktur dengan metode purposive sampling untuk periode 2012-2016. Pelepasan peringkat obligasi oleh PT. Pefindo dan ICMD 2012-2016. Rasio leverage yang terdiri dari Rasio Hutang terhadap Ekuitas (DER), Rasio Hutang terhadap Total Aset (DAR), Tingkat Imbalan Finansial (DFL), dan Rasio Cakupan Utang (DCR) tidak dapat memprediksi penghitungan obligasi perusahaan. Temuan penelitian menunjukkan bahwa leverage tidak berpengaruh pada peringkat obligasi.
\end{abstract}

JEL Classification G11, G24

DOI: https://doi.org/10.26905/afr.v1i2.2787 $\triangle$ Corresponding Author:

Deni Ramdani

Tel. /Fax. +6285647804422

E-mail:_deni.ramdani@untidar.ac.id

\section{PENDAHULUAN}

Obligasi menjadi instrumen yang menarik, baik bagi investor maupun perusahaan, bahkan pemerintah. Bagi investor kurang berani mengambil risiko tinggi, obligasi menjadi pilihan menarik. Obligasi memberikan bunga yang stabil. Investor akan memperoleh kupon yang dapat diterima secara rutin sampai jatuh tempo obligasi (Veronica, 2015). Namun obligasi juga mengandung risiko, yaitu ketika perusahaan tidak mampu membayar.

Risiko investasi obligasi relatif lebih rendah dibandingkan dengan investasi saham. Namun demikian, sebagai instrument investasi obligasi tetap mengandung risiko. Risiko yang muncul dalam investasi obligasi, yaitu kemungkinan ter- 
jadinya kegagalan perusahaan untuk membayar obligasi tersebut. Meskipun, pemeringkatan telah dilakukan bukan berarti memberikan jaminan keamanan investasi obliglasi. Pada tahun 2010 Mobile 8 Telekom gagal bayar bunga obligasi ke=12. Demikian juga FREN juga mengalami gagal bayar bunga obligasi, sehingga FREN disuspen obligasi dan sahamnya oleh BEI pada Maret 2009. Peringkat obligasi diturunkan oleh PEFINDO menjadi D dari CC.

Bagi emiten, obligasi merupakan sekuritas yang relatif aman karena biaya emisinya lebih murah dibandingkan saham. BAPEPAM mewajibkan obligasi untuk diperingkat, salah satu pemeringkat obligasi adalah PT. PEFINDO. Tujuan pemeringkatan adalah untuk menilai kinerja perusahaan. Kinerja obligasi memberikan signal tentang kegagalan hutang gagal bayar perusahaan. Lembaga pemeringkat rating atau rating agency merupakan lembaga yang berwenang untuk menentukan rating sebuah perusahaan. Lembaga-lembaga pemeringkat rating yang cukup terkenal di dunia antara lain adalah Standard \& Poor's Rating dan Moody's Rating. Di Indonesia, lembaga pemeringkat rating yang paling terkenal dan banyak digunakan oleh sebagian besar investor adalah rating yang diterbitkan oleh PT. PEFINDO. Perusahaan yang go public di Bursa Efek Indonesia (BEI) banyak yang menggunakan jasa pemeringkatan dari PT. PEFINDO.

Dalam proses pemeringkatan tidak ada key performance indicator (KPIs) yang jelas. PT. PEFINDO menggunakan beberapa kriteria yang berdasarkan pada revenue and cost structure, growth and stability, financial profile, dan regulatory framework. Untuk penilaian financial profile berdasarkan pada financial policy, cash flow protection, capital structure dan financial flexibility. Penilaian dilakukan secara menyeluruh dan mendalam sebagai dasar pemeringkatan suatu obligasi. Pemeringkatan suatu obligasi dapat digunakan sebagai informasi tingkat risiko suatu obligasi. Investor dapat menggunakan pemeringkatan obligasi untuk mengetahui risiko investasinya (Widowati, Nugrahanti, dan Kristanto, 2013; Raharja dan Sari, 2008).

Sampai saat ini belum ada penjelasan lebih lanjut mengenai aspek mana yang lebih diutamakan dalam pemeringkatan. Penelitian ini ingin menguji salah satu kriteria yang digunakan PT. PEFINDO dalam penilaian, yaitu kriteria keuangan. Kriteria keuangan yang digunakan dalam penelitian ini adalah dengan menggunakan variabel leverage yang termasuk dalam kriteria penilaian PT. PEFINDO pada profil keuangan struktur modal perusahaan. Leverage merupakan faktor yang berdampak pada pemeringkatan suatu obligasi. Leverage sutua perusaahn Temuan penelitian menunjukkan hasil yang tidak konsisten. Penelitian Hidayat (2018), Hernando dkk. (2018), Marfuah dan Endaryati (2016), Werasturi (2015), dan Raharja dan Sari (2008) leverage berpengaruh negatif terhadap peringkat obligasi. Sihombing dan Rachmawati (2015) menunjukkan leverage perusahaan tidak berpengaruh pada peringkat obligasi. Penelitian Thamida dan Lukman (2013) menunjukan bahwa reputasi auditor berpengaruh pada pemeringkatan obligasi. Noviana dan Solovida (2018) menunjukkan bahwa leverage berpengaruh pada yield obligasi.

Ketika meningkatkan leverage perusahaan target ketingkat dimana default risk bisa diminimalisir atau dikelola. Teori trade-off yang dinamis memprediksi bahwa pada titik refinancing profitabilitas yang lebih tinggi mengurangi kemungkinan kebangkrutan biaya dan meningkatkan leverage. Leverage banyak digunakan perusahaan untuk meningkatkan nilai perusahaan (firm's value). Hal ini dikarenakan adanya manfaat dari leverage yaitu dapat mengurangi beban pajak yang dibebankan kepada perusahaan. Selain memberikan dampak positif terhadap penghematan pajak, leverage juga memiliki dampak negatif.

Penelitian ini bertujuan untuk menganalisis pengaruh leverage, yang ditunjukkan oleh Debt to Equity Ratio, Debt to Total Assets Ratio, Degree of Financial Leverage, Debt Coverage Ratio terhadap terhadap peringkat obligasi. Variabel profitability dan firm's size sebagai variabel kontrol

\section{PENGEMBANGAN HIPOTESIS}

Keputusan pembiayaan perusahaan sangat penting bagi manajemen perusahaan. Keputusan ini termasuk penentuan struktur modal perusahaan yang optimal. Secara teoritis, ada sejumlah teori struktur modal yang tersedia dalam hal ini. Sejak Modigliani dan Miller (1958) mengemukakan teori yang tidak relevan, telah terjadi diskusi yang sedang berlangsung tentang relevansi struktur modal, namun secara teoritis ada agak bertentangan bukti tentang fenomena ini. yaitu dapat meningkatkan risiko kebangkrutan perusahaan. Oleh sebab itu, perusahaan dihadapkan kepada sebuah trade-off untuk menggunakan leverage atau tidak. Menurut Frank dan Goyal (2005), teori Modigliani dan Miller menyatakan bahwa hutang dapat memberikan manfaat pajak yang cukup besar bagi perusahaan. Berdasarkan teori tersebut, terdapat sebuah pertanyaan besar yaitu apakah seharusnya 
perusahaan menggunakan hutang yang lebih intensif untuk kemajuan perusahaan. Untuk menjawab pertanyaan tersebut maka perlu adanya perhitungan dan perkiraan yang baik mengenai manfaat dan biaya dari hutang (cost of debt). Lambrecht dan Myers (2012) menyarankan bahwa jika perusahaan menginginkan tingkat modal baik pengeluaran dan deviden, maka mereka harus membiarkan hutang berfluktuasi sebagai sisa.

Rasio Hutang terhadap Ekuitas adalah biasa digunakan sebagai ukuran struktur modal. Investor dan kreditur sangat tertarik pada rasio D/E sehingga bisa menganalisis penggunaan hutang dan peluang perusahaan secara berlebihan kebangkrutan. Sementara membuat keputusan pembiayaan, elemen tata kelola perusahaan seharusnya juga harus diingat. Ada konsep corporate governance baru yang muncul mendapatkan popularitas yang luas dalam dekade terakhir. Sambil membahas definisi perusahaan tata kelola, ada berbagai sudut pandang yang ditemukan yang sebenarnya bergantung pada milik seseorang persepsi tentang dunia Mekanisme tata kelola perusahaan dipandang sebagai kompleks sistem kontrol dari perspektif yang lebih luas (Rajan dan Zingales, 1998).

Sebuah perusahaan selalu ingin menerapkan struktur modal yang optimal. Struktur modal optimal sebuah perusahaan dapat didefinisikan sebagai struktur modal yang akan memaksimalkan harga saham perusahaan (Brigham and Houston, 2012: 451). Hal ini berarti perusahaan selalu berusaha meningkatkan nilai perusahaannya dengan cara mengoptimalkan struktur modalnya. Graham and Harvey (2001) menyatakan bahwa target struktur modal yang banyak digunakan oleh perusahaan untuk mengoptimalkan struktur modal perusahaan adalah dengan mengatur $45 \%$ dari struktur modal harus berasal dari hutang.

Kebijakan struktur modal merupakan trade off antara return dengan risiko. Hutang perusahaan yang meningkat, diharapkan mampu menjadi leverage perusahaan, namun potensi kebangkrutan perusahaan juag akan meningkat. Risiko yang semakin tinggi yang diakibatkan oleh besarnya hutang cenderung akan menurunkan harga saham atau nilai perusahaan, tetapi meningkatnya expected return juga diharapkan dapat meningkatkan harga saham atau nilai perusahaan. Bersadarkan hal tersebut, maka perusahaan akan berusaha mencapai struktur modal optimal. Struktur modal yang mengoptimalkan terjadi manakala terjadi keseimbangan antara risiko dan tingkat pengembalian. Harga saham dan nilai perusahaan akan meningkat manakala perusahaan mampu mencapai struktur modal yang optimal (Brigham and Houston, 2012: 451).

Perusahaan yang menggunakan hutang terlalu besar, sehingga leverage perusahaan meningkat, maka risiko perusahaan juga akan meningkat. Perusahaan akan berpotensi mengalami kesulitan keuangan, sehingga risiko kebangkrutan akan meningkat. Semakin tinggi risiko perusahaan, maka peringkat obligasi perusahaan akan cenderung turun. Beberapa penelitian menunjukkan bahwa semakin rendah leverage perusahaan, maka peringkat obligasi perusahaan akan cenderung meningkat (Hidayat (2018), Hernando dkk. (2018), Werasturi (2015), dan Raharja dan Sari (2008)).

Hipotesis dalam penelitian ini dapat dirumuskan sebagai berikut:

$\mathrm{H}_{1}$ : Debt to Equity Ratio berpengaruh terhadap peringkat obligasi.

$\mathrm{H}_{2}$ : Debt to Total Assets Ratio berpengaruh terhadap peringkat obligasi

$\mathrm{H}_{3}$ : Degree of Financial Leverage berpengaruh terhadap peringkat obligasi

$\mathrm{H}_{4}$ : Debt Coverage Ratio berpengaruh terhadap peringkat obligasi

\section{DATA DAN METODE}

Analisis data akan dilakukan dengan model analisis regresi ordinal. Menurut Chen dan Hughes (2004), metode regresi ordinal digunakan untuk memodelkan hubungan antara variabel dependen yang berskala ordinal. Kesimpulan umum yang mencakup pembangunan model untuk regresi ordinal memutuskan variabel mana yang harus dimasukkan pada model dan memilih fungsi hubungan (misalnya logit link atau complementary link) yang menunjukkan kesesuaian model. Estimasi model regresi ordinal untuk masing-masing variabel independen memberikan perkiraan dampak variabel tersebut terhadap variabel dependen setelah menyesuaikannya dengan variabel independen lainnya dalam model yang digunakan.

Penelitian ini menggunakan variabel dependen RAT (rating), yaitu peringkat obligasi yang berupa data ordinal. Variabel-variabel independen terdiri dari DER (Debt to Equity Ratio), DAR (Debt to Total Assets Ratio), DFL (Degree of Financial Leverage), DCR (Debt Coverage Ratio). Variabel kontrol terdiri dari PFT (profitability) dan SIZ (firm's size). Jenis data variabel independen dan variabel kontrol adalah data rasio.

Oleh sebab itu, penelitian ini dapat dianalisis dengan model analisis regresi ordinal. Permodelan penelitian terdiri dari 4 model. 
Model 1 untuk menguji variable bebas DER:

$\mathrm{RATi}=a 0+\beta 1 \mathrm{DERi}+\beta 2 \mathrm{PFTi}$

Model 2 untuk menguji variabel bebas DAR:

$\mathrm{RATi}=a 0+\beta 1 \mathrm{DARi}+\beta 2 \mathrm{PFTi}+\beta 3 \mathrm{SIZi}$

Model 3 untuk menguji variabel bebas DFL:

$\mathrm{RATi}=a 0+\beta 1 \mathrm{DFLi}+\beta 2 \mathrm{PFTi}+\beta 3 \mathrm{SIZi}$

Model 4, untuk menguji variabel bebas DCR:

$\mathrm{RATi}=a 0+\beta 1 \mathrm{DCRi}+\beta 2 \mathrm{PFTi}+\beta 3 \mathrm{SIZi}$

\section{HASIL}

Berdasarkan hasil pengujian model menunjukkan model yang digunakan, yaitu untuk model 1, 2, 3 dan 4 menunjukkan semua model yang digunakan fit dengan data yang digunakan (Tabel 1). Pada Model Fitting Information Model, -2 Log Likelihood menunjukkan bahwa untuk semua model, nilainya setelah dimasukkan variabel independen nilainya lebih rendah dibandingkan dengan nilai tanpa dimasukkan variable independen (intercept only) Nilai final (setelah memasukkan variable independen ke dalam model) semua model terjadi penurunan. Nilai chi-square untuk semua model tingkat probabilitasnya kurang dari 0,05. Data yang digunakan dalam penelitian ini menunjukkan berdistribusi normal. Pengujian multikolineritas menunjukkan tidak terjadi multikolineritas, karena nilai varians inflation factor (VIF) kurang dari 10.

Tabel 1. Fitting Information Model

\begin{tabular}{|c|c|c|c|c|c|c|c|c|}
\hline & \multicolumn{3}{|c|}{ Model 1} & \multirow{2}{*}{$\begin{array}{c}\text { Model } 2 \\
\text { Final }\end{array}$} & \multicolumn{3}{|c|}{ Model 3} & \multirow{2}{*}{$\begin{array}{c}\text { Model } 4 \\
\text { Final }\end{array}$} \\
\hline & $\begin{array}{l}\text { Intercept } \\
\text { Only }\end{array}$ & Final & $\begin{array}{l}\text { Intercept } \\
\text { Only }\end{array}$ & & $\begin{array}{l}\text { Intercept } \\
\text { Only }\end{array}$ & Final & $\begin{array}{l}\text { Intercept } \\
\text { Only }\end{array}$ & \\
\hline -2 Log Likelihood & 382,169 & 375,393 & 382,169 & 369,86 & 382,169 & 370,52 & 382,169 & 365,899 \\
\hline Chi-Square & & 6,776 & & 12,309 & & 11,649 & & 16,269 \\
\hline Probabilitas & & 0,034 & & 0,006 & & 0,009 & & 0,001 \\
\hline
\end{tabular}

Nilai Pseudo R-Square digunakan untuk menguji kesesuaian statistik. Nilai tersebut menunjukkan bahwa seberapa besar variabel independen mampu menjelaskan variabel dependen. Nilai ini sama seperti halnya koefisien determinasi pada regresi. Terdapat tiga buah nilai Pseudo $R$ Square, dengan nilai terbesar adalah Nagelkerke. Berdasarkan nilai Pseudo R-Square dengan varia- ble profitabilitas dan ukuran perusahaan sebagai variabel kontrol menunjukkan bahwa variable DCR (Model 4) mampu menjelaskan peringkat obligasi yang paling tinggi, yaitu sebesar 15,4\%. Hasil analisis dari nilai Pseudo R-Square menunjukkan rata-rata (untuk semua model) menunjukkan kemampuan leverage tidak terlalu besar untuk menjelaskan peringkat obligasi.

Tabel 2. Pseudo R-Square

\begin{tabular}{lrrrrrr}
\hline & $\begin{array}{l}\text { Model 1 } \\
\text { Bebas DER }\end{array}$ & Variabel & $\begin{array}{l}\text { Model 2 } \\
\text { Bebas DAR }\end{array}$ & Variabel & $\begin{array}{l}\text { Model 3 Variabel } \\
\text { Bebas DFL }\end{array}$ & $\begin{array}{l}\text { Model } \\
\text { Bebas DCR }\end{array}$ \\
\hline Cox and Snell & 0,066 & 0,116 & 0,10 & 0,15 \\
Nagelkerke & 0,067 & 0,118 & 0,112 & 0,154 \\
McFadden & 0,018 & 0,032 & 0,03 & 0,043 \\
\hline
\end{tabular}

Hal ini menunjukkan bahwa masih banyak faktor-faktor lain yang mempengaruhi peringkat obligasi selain faktor DER, DAR, DFL, DCR dan profitabilitas, seperti pertumbuhan industri dan stabilitas (growth and stability), pendapatan dan struktur biaya (revenue and cost structure), hambatan masuk dan tingkat persaingan dalam industri (barriers to entry and competition), regulasi dan deregulasi industri (regulatory framework), serta profil keuangan dari industri (financial profile) yang berupa perlindungan arus kas (cash flow protection) dan fleksibilitas keuangan (financial flexibility) perusahaan.
Test of Parallel Lines dipergunakan untuk melihat apakah terdapat kesamaan kategori antara variabel-variabel pada model. Test of Parallel Lines juga digunakan untuk menguji asumsi bahwa setiap kategori memiliki parameter yang sama atau hubungan antara variabel independen dengan logit adalah sama untuk semua. Hasil analisis tidak terda pat perbedaan katagori antara variabelvariabel yang digunakan dalam penelitian (Model 1, 2, 3 dan 4). Berdasarkan uji statistik dengan menggunakan Test of Parallel Lines, maka model dengan logit dapat diterima atau model fit dengan data. Dengan demikian, model 1 ini dapat di- 
pergunakan dan uji hipotesis dapat dilakukan

(Tabel 3).

Tabel 3. Test of Parallel Lines Model

\begin{tabular}{|c|c|c|c|c|c|c|c|c|}
\hline \multirow[b]{2}{*}{ Model } & $\begin{array}{l}\text { Model } 1 \\
\text { Bebas DER }\end{array}$ & Variabel & \multicolumn{2}{|c|}{$\begin{array}{l}\text { Model } 2 \\
\text { Variabel Bebas DAR }\end{array}$} & \multicolumn{2}{|c|}{$\begin{array}{l}\text { Model } 3 \text { Variabel } \\
\text { Bebas DFL }\end{array}$} & \multicolumn{2}{|c|}{$\begin{array}{l}\text { Model } 4 \text { Variabel Bebas } \\
\text { DCR }\end{array}$} \\
\hline & Ho & General & Ho & General & Ho & General & Ho & General \\
\hline $\begin{array}{l}-2 \text { Log Likeli- } \\
\text { hood }\end{array}$ & 375,393 & 366,226 & 369,86 & 344,012 & 370,52 & 343,481 & 365,899 & 358,166 \\
\hline Chi-Square & & 9,167 & & 25,847 & & 27,039 & & 7,734 \\
\hline Probabilitas & & 0,689 & & 0,103 & & 0,078 & & 0,982 \\
\hline
\end{tabular}

\section{PEMBAHASAN}

Berdasarkan hasil analisis menunjukkan bahwa bahwa leverage tidak berpengaruh terhadap peringkat obligasi. Hasil penelitian ini tidak sejalan dengan temuan penelitian Sihombing dan Rachmawati (2015) dimana leverage perusahaan tidak berpengaruh pada peringkat obligasi. Hasil penelitian inimendukung temuan peneltian yang dilakukan Henny (2016). Magreta dan Nurmayanti (2009). Temuan Marfuah (2012) menunjukkan bahwa debt maturity juga tidak berpengaruh terhadap peringkat obligasi. Namun, temuan penelitian ini tidak sejalan dengan penelitian Hidayat (2018), Hernando dkk. (2018), Werasturi (2015), Murcia, at al. (2014), Purwaningsih (2013), Septyawanti (2013) dan Raharja dan Sari (2008) dimana leverage berpengaruh negatif terhadap peringkat obligasi. Sedangkan penelitian Rusfika dan Wahidahwati (2017), Widowati dan Kristanto (2013) menunjukkan leverage berpengaruh positif terhadap peringkat obligasi.

Leverage yang diproksikan dengan debt to equity ratio, debt to total asset ratio, degree of financial leverage dan debt coverage ratio menunjukkan tidak berpengaruh terhadap peringkat obligasi. Hal ini menunjukkan bahwa pemeringkatan yang dilakukan oleh PEFINDO leverage perusahaan bukan menjadi determinan utama. Hal ini terjadi karena leverage perusahaan hanya salah komponen saja, dari komponen profil keuangan perusahaan. Hutang sebagai sumber pembiayaan perusahaan, pada perusahaan yang masuk dalam pemeringkatan PEFINDO masih dalam posisi yang relatif aman. Besarnya hutang tidak berpotensi terjadinya kesulitan keuangan ataupun potensi kebangkrutan.

Faktor yang mempengaruhi peringkat lebih obligasi cenderung di luar leverage perusahaan. Faktor tersebut lebih banyak mengacu pada kebijakan keuangan, tingkat revenue atau profitabilitas, pertumbuhan dan stabilitas perusahaan. Profitabilitas, pertumbuhan dan stabilitas perusahaan menjadi penting dalam pemeringkatan obligasi. Ketiga faktor tersebut dapat dipakai sebagai indikator bagaimana prospek perusahaan di masa yang akan datang.

\section{SIMPULAN DAN SARAN}

Penelitian ini bertujuan untuk menganalisis pengaruh leverage perusahaan terhadap peringkat obligasi, dengan profitabilitas dan ukuran perusahaan sebagai variabel kontrol. Hasil penelitian menunjukan bahwa leverage tidak berpengaruh terhadap peringkat obligasi. Besar kecilnya hutang yang tercermin pada debt to equity ratio, debt to total asset ratio, degree of financial leverage dan debt coverage ratio tidak berpengaruh terhadap peringkat obligasi. Pemeringkatan obligasi lebih cenderung mendasarkan bukan pada leverage, namun pada kinerja perusahaan yang ditunjukkan dari ptofitabilitas, pertumbuhan dan stabilitas perusahaan.

Penelitian ini terbatas hanya membahas terkait dengan leverage, sebagai variabel prediktor dengan objek penelitian pada perusahaan yang masuk dalam daftar pemeringkatan yang dikeluarjan oleh PEFINDO antara tahun 2012-2016. Dalam rangka pengembangan keilmuan dan kemanfaatan penelitian, maka penelitian selanjutnya dapat menambahkan pertumbuhan dan stabilitas perusahaan dan variabel makro ekonomi sebagai indikator risiko bisnis. Selain itu waktu penelitian dapat diperpanjang lagi, sehingga dapat diketahui juga bagaimana siklus bisnis.

\section{DAFTAR PUSTAKA}

Amalia, N. (2013). Pemeringkatan Obligasi PT Pefindo: Berdasarkan Informasi Keuangan. Accounting Analysis Journal. 2 (2):139-147.

Almilia, L. S. dan Devi, V. (2007). FaktorFaktor yang Mempengaruhi Prediksi Peringkat Obligasi pada Perusahaan Manufaktur 
yang Terdaftar di Bursa Efek Indonesia. Prosiding Seminar Nasional Manajemen SMART Bandung: 1-23.

Brigham, E.F. dan Houston, J.F. (2012). Essentials of Financial Management, 2nd edition. Singapore: Cengage Learning Asia Pte Ltd.

Chen, C.K. and Hughes, J. (2004) Using Ordinal Regression Model to Analyse Student Satisfaction Questionnaires. Journal of IR Applications.

Frank, M.Z. and Goyal, V.K. (2005). Trade-off and Pecking Order Theories of Debt. Working Paper. Preliminary. Final version to appear in B. Espen Eckbo (ed.), Handbook of Corporate Finance: Empirical Corporate Finance (Handbooks in Finance Series, Elsevier/North-Holland), Chapter 7.

Graham, JR. dan Harvey, C.R. (2001). The Theory and Practice of Corporate Finance: Evidence from the Field. Journal of Financial Economics. 60 (May): 187-243.

Henny (2016). Pengaruh Faktor Akuntansi Terhadap Prediksi Peringkat Obligasi. Jurnal Akuntansi. 20(1): 52-69

Hernando, A., Miranda, E., Luvena Aileen, L. dan Nurul, A. (2018). Faktor-Faktor Determinan Peringkat Obligasi Perusahaan Go Public Non-Keuangan di Indonesia. Jurnal Riset Akuntansi \& Keuangan. 6(2): 173-186

Hidayat, W.W. (2018). Pengaruh Leverage dan Likuiditas Terhadap Peringkat Obbligasi: Stusi Kasus Perusahaan Non Keuangan Di Indonesia. Jurnal Riset Manajemen dan Bisnis (JRMB). 3(3): 387-394.

Lambrecht, B.M., \& Myers, S. C. (2012). A Lintner Model of Payout and Managerial Rents. The journal of finance. 67(5), 17611810.

Marfuah dan Endaryati, H. (2016). Pengaruh Good Corporate Governance dan Debt Maturity Terhadap Bond Rating. Ekuitas: Jurnal Ekonomi dan Keuangan. 20(4): 434 454.

Magreta dan Nurmayanti, P. (2009). FaktorFaktor Yang Mempengaruhi Prediksi Peringkat Oblogasi Ditinjau Dari Faktor
Akuntansi dan Non Akuntansi. Jurnal Bisnis dan Akuntansi. 11(3): 143-154.

Modigliani, F. and Merton H. Miller, M.H. (1958). The Cost of Capital, Corporation Finance and the Theory of Investment. The American Economic Review. 48(3): 261297.

Murcia, F.C.S., Murcia, D., Rover, S., Borba, J.A. (2014). The Determinants of Credit Rating: Brazilian Evidence. Rio de Jeneiro: Brazilian Administration Review. On-line version ISSN. 11 (2).

Noviana, L. dan Solovida, G.T. (2018). Pengaruh Likuiditas, Leverage, Rating Obligasi Syariah, Risiko Obligasi Syariah Terhadap Yield Obligasi (Sukuk). STABILITY Journal of Management \& Business. 1(2)

Purwaningsih, S. (2013). Faktor Yang Mempengaruhi Rating Sukuk Yang Ditinjau Dari Faktor Akuntansi dan Non Akuntansi. Accounting Analysis Journal. 2(3).

Raharja dan Sari, M. (2008). Kemampuan Rasio Keuangan Dalam Memprediksi Peringkat Obligasi (PT. Kasnic Credit Rating). Jurnal Maksi. 8(2): 212-232.

Rajan, R.G and Zingales, L. (1998). Power in a Theory of the Firm. The Quarterly Journal of Economics. 113(2): 387-432.

Rusfika dan Wahidahwati. (2017). Kemampuan Faktor Akuntansi dan Non Akuntansi Dalam Memprediksi Bond Rating. Ekuitas: Jurnal Ekonomi dan Keuangan. 1(1): 85103

Septyawanti, H.I. (2013). Faktor-faktor yang Mempengaruhi Peringkat Obligasi Perusahaan. Accounting Analysis Journal. 2(3): 276-285

Sihombing, H.J. dan Rachmawati, E.N. (2015). Faktor-Faktor Yang Mempengaruhi Peringkat Obligasi Pada Perusahaan Yang Terdaftar Di Bursa Efek Indonesia. Jurnal Ekonomi, Manajemen dan Akutansi. 24 (1)

Thamida, N dan Lukman. H. (2013). Analisis Faktor-Faktor yang Mempengaruhi Peringkat Obligasi Pada Industri Perbankan Yang Terdaftar di Bursa Efek Indonesia 2008-2012. Jurnal Akuntansi. 17(2): 198- 
211.

Veronica, A. (2015). Faktor-Faktor yang Mempengaruhi Peringkat Obligasi Pada Perusahaan Manufaktur. Jurnal Manajemen dan Bisnis Sriwijaya. 13(2): 271-282.

Werasturi, D.N.S. (2015). Analisis Prediksi Peringkat Obligasi Perusahaan Dengan Pendekatan GFaktor Keuangan dan Non Keuangan. Jurnal Dinamika Akuntansi. 7(1): 63-74.

Widowati, D. dan Kristanto, N.A. (2013). Analisis Faktor Keuangan dan Non Keuangan yang Berpengaruh Pada Prediksi Peringkat Obligasi Di Indonesia. Jurnal Manajemen. 13 (1): 35-53. 